\title{
Indigenous knowledge and potential of termites as poultry feed in Burkina Faso
}

\author{
F. Sankara ${ }^{1}$, S. Pousga ${ }^{1}$, N.C.A. Dao ${ }^{1}$, D.S.J.C Gbemavo ${ }^{2}$, V.A. Clottey ${ }^{3}$, K. Coulibaly ${ }^{1}$, J.P. Nacoulma ${ }^{1}$, S. Ouedraogo ${ }^{1}$ \\ and M. Kenis ${ }^{4}$ \\ ${ }^{1}$ Institut du Développement Rural, Université Nazi Boni, $01 B P 1091$ Bobo 01, Bobo-dioulasso, Burkina Faso; ${ }^{2}$ Laboratoire \\ de Biomathématiques et d'Estimations Forestières (LABEF), Faculté des Sciences Agronomiques/Université d'Abomey- \\ Calavi, 04 BP 1525, Cotonou, Bénin; ${ }^{3}$ CABI, CSIR Campus, P.O. Box CT 8630, Cantonments, Accra, Ghana; ${ }^{4}$ CABI, Rue \\ des Grillons 1, 2800 Delémont, Switzerland; ferdisank2005@yahoo.fr
}

Received: 1 November 2017 / Accepted: 8 June 2018

(c) 2018 Wageningen Academic Publishers

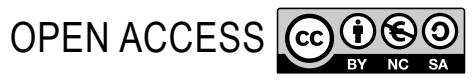

RESEARCH ARTICLE

\begin{abstract}
The purpose of this study, carried out in eight regions in Burkina Faso, West Africa, was to assess the use and knowledge of termites in poultry nutrition in Burkina Faso and to analyse the factors influencing this use. Household surveys were conducted to collect data on the socio-demographic characteristics of poultry farmers and the use of termites in poultry feed. These surveys involved 1,100 farmers in 32 villages. Poultry farmers mostly raise chicken and guinea fowls and these two species are also those that receive termites as supplementary feed. $78 \%$ of the surveyed farmers use termites to feed their poultry, but the rate strongly varied among regions and provinces. Several reasons were given for not using termites, the most common being the unavailability of termites followed by the lack of time and not being aware of the technique. Farmers were aware of termite species they consider as toxic in feeding chicks. Understanding the link between the use and availability of termites in poultry nutrition in West Africa is an important step towards the improvement of poultry production.
\end{abstract}

Keywords: Burkina Faso, insects as feed, poultry, termite use

\section{Introduction}

Poultry farming in Burkina Faso, as elsewhere in West Africa, plays an important role in the daily life of the rural farmers, who raise village chickens for several purposes (Kondombo et al., 2003; Pousga et al., 2007b). Local poultry is appreciated for its superior taste, justifying the existence of marketing systems to provide the cities with poultry products from the rural areas (Ouedraogo, 2002; Pousga et al., 2007b). Poultry meat and eggs provide protein and energy (Ouedraogo, 2005) and contribute to food security (Kagone, 1999). However, poultry producers suffer from the increasing cost of feed (representing up to $70 \%$ of the total production costs) whereas smallholder farmers that maintain scavenging poultry as a side activity also suffer from quantitative and qualitative food shortages (Pousga et al., 2007a,b), affecting production of chicken and eggs, and reducing family income. In Burkina faso, cereals represent the basic food for chickens and guinea fowls (Nougtara, 2011; Savadogo, 1995). Animal proteins, e.g. fish meal, meat meal and blood meal are usually imported and are very expensive for poultry producers and rarely used by smallholder farmers (Pousga and Boly, 2009). Plant protein sources, like cotton and groundnut cake, are not readily available for poultry because they are more commonly used in ruminant feed (Pousga et al., 2007a). The limited amount of quality feed partly explains the low performances observed in traditional poultry farming in Burkina Faso.

Insects represent a sustainable source of proteins that can be used as human food and animal feed (Anankware et al., 2015; Van Huis et al., 2013). Termites are among the most nutritious insects and among the most widely consumed by humans (Lavalette, 2013).

They are also widely used by smallholder farmers to feed poultry in Africa, including Burkina Faso, being given as supplement, in particular during the rainy season (Diawara, 2013; Kenis et al., 2014; Savadogo, 1995). Termites are typically obtained by breaking termite mounds or by 
trapping them with inverted pots filled with organic material (Chrysostome et al., 2009; Diawara, 2013; Farina et al., 1991). However, termites are usually given in very small quantities and fowls have to find most of their proteins by scavenging around farms (Hien et al., 2005).

Thus, there is an urgent need to improve traditional poultry feed quality, in particular by facilitating access to insect proteins. The use of termites could be enhanced but, for this a better knowledge of the traditional practices is needed. This paper quantifies the use of termites for poultry feed in Burkina Faso and assesses the relationship among the utilisation and availability of termites in traditional poultry farming in the country.

\section{Material and methods}

\section{Study area}

The study was carried out in eight regions in Burkina Faso, i.e. Centre Ouest, Plateau Central, Nord, Centre Sud, Sahel, Hauts Bassins, Cascades and Est (Figure 1). The regions were selected to cover all three climatic zones of Burkina Faso. These are, from north to south:

1. The Sahelian zone (regions Sahel and part of Nord), situated approximatively north of the $13^{\circ} 30^{\prime}$ parallel is defined as a zone experiencing $350-600 \mathrm{~mm}$ precipitations that are irregular and unevenly distributed over time and space. Temperatures often reach $40^{\circ} \mathrm{C}$, especially in the hot dry season.

2. The North Sudanian zone, or Sudano-Sahelian zone (Centre Ouest, Plateau Central, Est and part of Nord and Centre Sud) is situated approximatively between the $11^{\circ} 30^{\prime}$ and $13^{\circ} 30^{\prime}$ parallel, where average annual precipitations vary between 600 and $900 \mathrm{~mm}$.

3. The South Sudanian zone (Hauts Bassins, Cascades and part of Centre Sud) is situated approximatively south of the $11^{\circ} 30^{\prime}$ parallel. It receives from 900 to $1,300 \mathrm{~mm}$ precipitations annually. This zone experiences milder temperatures.

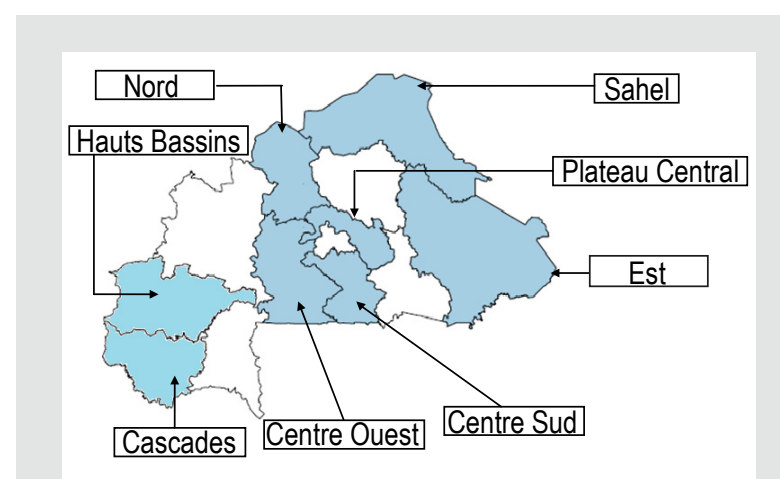

Figure 1. Regions of Burkina Faso where the study took place.
Maps of the climatic zones and details of the vegetation and agricultural practices in the zones and regions are found in Dembele (2010). Table 1 indicates the agro-climatic zone in which the surveyed villages are situated. Further data on the climate of regions included in this study are found, e.g. in INSD (2014).

\section{Surveys}

A total of 1,100 poultry farmers in 32 villages in 25 provinces of the eight regions were interviewed individually from 22 May 2015 to 16 July 2015 (Table 1). In each region, the choice of provinces and villages was based on the number of inhabitants, the accessibility and the proportion of poultry farmers in the localities. The choice of provinces and villages was facilitated by the agents of the Ministry of Animal Resources of Burkina Faso. Inside each province, the villages with the highest number of inhabitants were chosen (INSD, 2008). But to ensure geographic diversity in the samples, they were also selected on different roads. Farmers were randomly selected from lists provided by the Village Development Committees.

In six regions, 30 farmers were selected in each of the five villages per region, whereas 100 farmers were selected from only one village each in Hauts Bassins and Cascades. Direct, face-to-face interviews were conducted by two Master students who understand and speak the local languages of the different villages. The respondents were all farm managers. Surveys were made with a semi-structured questionnaire to collect socio-demographic data of the population, viz: name; age; sex; education level; and profession.

\section{Socio-demographic studies of the studied zones}

Table 2 shows the general characteristics of the surveyed population. More men (83.17\%) than women were interviewed (Table 2) and most of them were married (96.61\%). The majority were crop farmers $(78.50 \%)$ and had poultry farming as a secondary occupation (91.7\%). Many of the respondents had no formal education and used termites (78.04\%). More than half (64.5\%) of the respondents had not been to primary school. Less than 7\% (6.7\%) have had high school education.

\section{Statistical analyses}

Interviewed poultry farmers were first described and put into two groups: (1) termite users; and (2) non-users. Data from 1,093 respondents were further used in the analysis. The two groups of poultry farmers (termite users and non-users) were separately analysed using descriptive statistics (effective and frequency). All the factors being qualitative (region, province, ethnicity, sex, marital status, instruction level, main occupation, secondary occupation), 
Table 1. Distribution of surveyed households per village in the provinces of the regions, and climatic zone of the villages.

\begin{tabular}{|c|c|c|c|c|}
\hline Regions & Provinces & Villages and hamlets & $\begin{array}{l}\text { No. of households } \\
\text { surveyed/village }\end{array}$ & Climatic zone ${ }^{1}$ \\
\hline \multirow[t]{5}{*}{ Centre Ouest } & Sanguier & Kion & 30 & NS \\
\hline & & Hamlets & 30 & NS \\
\hline & Boulkiemde & Poa & 30 & NS \\
\hline & Ziro & Kation & 30 & NS \\
\hline & Sissili & To & 30 & NS \\
\hline \multirow[t]{5}{*}{ Plateau Central } & Oubritenga & Ourgou-Manega & 30 & NS \\
\hline & & Lindi & 30 & NS \\
\hline & Ganzourgou & Salogo & 30 & NS \\
\hline & Kourweogo & Niou & 30 & NS \\
\hline & & Hamlets & 30 & NS \\
\hline \multirow[t]{5}{*}{ Nord } & Yatenga & Oula & 30 & $S$ \\
\hline & & Boursouma & 30 & $S$ \\
\hline & Loroum & Solobo & 30 & $S$ \\
\hline & Zondoma & Danaoua & 30 & NS \\
\hline & Passore & Rana & 30 & NS \\
\hline \multirow[t]{5}{*}{ Centre Sud } & Bazega & Tuili & 30 & NS \\
\hline & Nahouri & Banon & 30 & SS \\
\hline & & Tiakané & 30 & SS \\
\hline & Zoundweogo & Yimasga & 30 & NS \\
\hline & & Basgana & 30 & NS \\
\hline \multirow[t]{5}{*}{ Sahel } & Seno & N'djomga & 30 & $S$ \\
\hline & & Korea & 30 & $S$ \\
\hline & Soum & Pobe-mengao & 30 & $S$ \\
\hline & Oudalan & Alliakoum & 30 & $S$ \\
\hline & Yagha & lbbal & 30 & $S$ \\
\hline \multirow[t]{5}{*}{ Est } & Tapoa & Sambalgou & 30 & NS \\
\hline & Gnagna & Boungou-Folgou & 30 & $S$ \\
\hline & Komandjari & Oue & 30 & NS \\
\hline & Gourma & Diapangou & 30 & NS \\
\hline & Kompienga & Bombontangou & 30 & NS \\
\hline Cascades & Comoe & Siniena & 100 & SS \\
\hline Hauts-Bassins & Houet & Gombeledougou & 100 & SS \\
\hline
\end{tabular}

the independence between the proportions of termites users and non-users was tested by chi-square. The effect of different factors on termite use was examined using the binomial regression model. A step-by-step selection of the variables was made before adjusting the model to the data to avoid correlations between the model's explanatory variables. The stepwise regression incorporated both the forward and backward selection approaches and the final model considered only significant explanatory variables. The homogeneity test, the choice of variables and the adjustment of the binomial model to the data were carried out using R3.3.2 (R Development Core Team, http://www.Rproject.org).

\section{Results}

\section{Use of termites}

About $78 \%$ of the farmers said that they give termites to their poultry at least occasionally. The majority of the termite users were male (84.64\%), married (97.07\%), had no formal education (65.89\%) and had crop farming (79.72\%) as their main occupation (Table 3). In three regions, Centre Ouest, Hauts Bassins and Nord, farmers used termites more extensively than in other regions. In contrast, in some provinces of the Sahel and Est regions, hardly any farmers use them. 
Table 2. Descriptive statistics of the surveyed sample.

\begin{tabular}{|c|c|c|c|}
\hline Qualitative factors & Factors levels & Size & Percentage \\
\hline \multirow[t]{2}{*}{ Termites user groups } & G1 (termite users) & 853 & 78.04 \\
\hline & G2 (non-termite user) & 240 & 21.96 \\
\hline \multirow[t]{8}{*}{ Region } & Cascades & 100 & 9.15 \\
\hline & Centre-Ouest & 150 & 13.72 \\
\hline & Centre-Sud & 147 & 13.45 \\
\hline & Est & 149 & 13.63 \\
\hline & Hauts-Bassins & 99 & 9.06 \\
\hline & Nord & 150 & 13.72 \\
\hline & Plateau Central & 150 & 13.72 \\
\hline & Sahel & 148 & 13.54 \\
\hline \multirow[t]{2}{*}{ Sex } & female & 184 & 16.83 \\
\hline & male & 909 & 83.17 \\
\hline \multirow[t]{4}{*}{ Marital status } & single & 16 & 1.46 \\
\hline & divorced & 11 & 1.01 \\
\hline & married & 1,056 & 96.61 \\
\hline & widowed & 10 & 0.91 \\
\hline \multirow[t]{4}{*}{ Educational level } & other & 142 & 12.99 \\
\hline & none & 705 & 64.50 \\
\hline & primary & 172 & 15.74 \\
\hline & secondary & 74 & 6.77 \\
\hline \multirow[t]{7}{*}{ Principal occupation } & agent & 11 & 1.01 \\
\hline & crop farmer & 858 & 78.50 \\
\hline & artisan & 8 & 0.73 \\
\hline & other & 10 & 0.91 \\
\hline & trader & 12 & 1.10 \\
\hline & poultry farmer & 88 & 8.05 \\
\hline & household & 106 & 9.70 \\
\hline \multirow[t]{6}{*}{ Secondary occupation } & crop farmer & 85 & 7.78 \\
\hline & artisan & 1 & 0.09 \\
\hline & other & 1 & 0.09 \\
\hline & trader & 2 & 0.18 \\
\hline & poultry farmer & 1,003 & 91.77 \\
\hline & household & 1 & 0.09 \\
\hline
\end{tabular}

The proportions of termite users varied significantly $(P<0.05)$ for each level of the different factors studied (Table 3). The stepwise regression selected three factors from the eight: province, sex and main occupation. The result of the binomial regression showed that two of the three factors are determinants of the use of termites: province and main occupation $(P<0.0001)$. The detailed result of the binomial regression (Table 4) showed that the provinces of Comoe, Kourweogo, Nahouri, Sanguier, Sissili and Tuy and the main occupations: crop farmer, poultry farmer and housewife positively affected the use of termites by the surveyed poultry farmers. On the other hand, the poultry farmers in the province of Gnagna had a high probability of not using termites.
Table 3. Statistics of the termite and non-termite users.

\begin{tabular}{|c|c|c|c|}
\hline Qualitative factors & Factor levels & G1 (\%) & G2 (\%) \\
\hline \multirow[t]{9}{*}{ Region } & Cascades & 10.20 & 5.42 \\
\hline & Centre-Ouest & 16.06 & 5.42 \\
\hline & Centre-Sud & 14.30 & 10.42 \\
\hline & Est & 9.96 & 26.67 \\
\hline & Hauts-Bassins & 10.67 & 3.33 \\
\hline & Nord & 16.30 & 4.58 \\
\hline & Plateau Central & 14.30 & 11.67 \\
\hline & Sahel & 8.21 & 32.50 \\
\hline & $P$ & & $<0.0001$ \\
\hline \multirow[t]{3}{*}{ Sex } & female & 15.36 & 22.08 \\
\hline & male & 84.64 & 77.92 \\
\hline & $P$ & & $<0.05$ \\
\hline \multirow[t]{5}{*}{ Marital status } & single & 1.29 & 2.08 \\
\hline & divorced & 1.06 & 0.83 \\
\hline & married & 97.07 & 95.00 \\
\hline & widowed & 0.59 & 2.08 \\
\hline & $P$ & & $<0.0001$ \\
\hline \multirow[t]{5}{*}{ Educational level } & other & 10.43 & 22.08 \\
\hline & none & 65.89 & 59.58 \\
\hline & primary & 17.12 & 10.83 \\
\hline & secondary & 6.57 & 7.50 \\
\hline & $P$ & & $<0.0001$ \\
\hline \multirow[t]{8}{*}{ Principal occupation } & agent & 0.47 & 2.92 \\
\hline & crop farmer & 79.72 & 74.17 \\
\hline & artisan & 0.70 & 0.83 \\
\hline & other & 0.82 & 1.25 \\
\hline & trader & 0.82 & 2.08 \\
\hline & poultry farmer & 6.92 & 12.08 \\
\hline & household & 10.55 & 6.67 \\
\hline & $P$ & & $<0.0001$ \\
\hline
\end{tabular}

Sixteen reasons were given for not using termites (Table 5). In Sahel and Est regions, where termites are less used, the most commonly given reason was the unavailability of termites. Lack of time and lack of awareness of the capturing technique were other common reasons given by respondents.

In all regions, the poultry species most commonly given termites as supplements were chickens, followed by guinea fowls (Figure 2). Turkey, duck and pigeon were also occasionally cited. Figure 3 shows the percentage of owners of poultry species that feed them with termites. The majority of chickens, guinea fowls and turkey owners feed them with termites whereas ducks and pigeons are rarely fed with termites. 
Table 4. Result of the binomial linear regression per province.

$\begin{array}{lccl}\text { Factor } & \text { Coefficient } & \text { Error-type } & \text { Probability } \\ \text { (Intercept) } & & & \\ \text { Boulkiemde } & -2.845 & 1.028 & <0.01 \\ \text { Comoe } & 1.105 & 0.662 & >0.05 \\ \text { Ganzourgou } & 1.412 & 0.502 & <0.01 \\ \text { Gnagna } & 1.061 & 0.664 & >0.05 \\ \text { Gourma } & -3.429 & 0.828 & <0.001 \\ \text { Komandjari } & -0.460 & 0.534 & >0.05 \\ \text { Kompienga } & -0.015 & 0.548 & >0.05 \\ \text { Kourweogo } & 0.861 & 0.612 & >0.05 \\ \text { Loroum } & 1.370 & 0.562 & <0.05 \\ \text { Nahouri } & 18.291 & 1,141.063 & >0.05 \\ \text { Oubritenga } & 3.274 & 1.080 & <0.01 \\ \text { Oudalan } & 0.501 & 0.502 & >0.05 \\ \text { Passoré } & -19.092 & 1,184.269 & >0.05 \\ \text { Sanguie } & 18.30 & 1,142.14 & >0.05 \\ \text { Seno } & 2.392 & 0.706 & <0.01 \\ \text { Sissili } & -0.061 & 0.497 & >0.05 \\ \text { Soum } & 2.777 & 1.100 & <0.05 \\ \text { Tapoa } & -0.189 & 0.555 & >0.05 \\ \text { Tuy } & 0.372 & 0.581 & >0.05 \\ \text { Yagha } & 1.928 & 0.552 & <0.001 \\ \text { Yatenga } & -0.149 & 0.578 & >0.05 \\ \text { Ziro } & 1.011 & 0.561 & >0.05 \\ \text { Zondoma } & 1.300 & 0.678 & >0.05 \\ \text { Zoundweogo } & 17.949 & 1,175.053 & >0.05 \\ \text { Male } & 0.403 & 0.493 & >0.05 \\ \text { PPCrop farmers } & 0.478 & 0.327 & >0.05 \\ \text { PPArtisan } & 3.157 & 0.911 & <0.01 \\ \text { PPOther } & 1.648 & 1.223 & >0.05 \\ \text { PPTrader } & 1.366 & 1.185 & >0.05 \\ \text { PPPoultry farmer } & 1.659 & 1.110 & >0.05 \\ \text { PPHousewife } & 2.709 & 0.956 & <0.01 \\ & 3.467 & 0.993 & <0.001 \\ & & & \end{array}$

\section{Discussion}

Traditional poultry farming is practiced by most farmers in Burkina Faso (Traore, 2006). This survey among 1,100 households in eight regions represents the first survey at that scale on the use of termites to feed poultry in West Africa. About $78 \%$ of the farmers said that they give termites to their poultry, mostly chickens and guinea fowls. Termite users were mostly male, married, had no formal education and had crop farming as their main occupation. The higher number of men than women among the respondents is due to the fact that, in Burkina Faso, household interviews are typically answered by men who are the heads of farms and, in many regions, are responsible for poultry farming.

The very high number of farmers using termites as poultry feed in at least six of the eight surveyed regions shows that farmers are well aware of the need to use protein in poultry nutrition. According to farmers, the collection of termites and its use in poultry feed is an ancestral know-how. For example, most farmers were able to recognise species that are considered as 'toxic' and explained that the toxicity would be due mainly to the large mandibles that would injure or kill chicks when eaten. The most commonly eaten termite species were the large Macrotermes species. They are the winged termites that emerge after the rains from holes near termite nests (Anankware et al., 2015). Van Huis (2003) observed that, in Africa, locals beat the ground around termite hills (simulating heavy rain) to provoke the termites to emerge. Macrotermes species are suitable both for animals and for humans. Ntukuyoh et al. (2012) showed that Macrotermes bellicosus have high nutritional qualities. Queen, soldiers and workers were analysed for proximate composition, vitamin, mineral elements and anti-nutrient content. They concluded that $M$. bellicosus is a good source of protein and other microand macro-nutrients and they are harmless to eat. More generally, termites are the second most eaten insects all over the world (Chung, 2010).

Chickens and guinea fowls are the two species whose feed were mostly supplemented with termites, in all regions where the investigation was carried out. These results corroborate those of Boko et al. (2012) who had also shown that, in subSaharan Africa, termites are mainly given to chickens and guinea fowls. These two species are also the most commonly found on farm because they are easy to rear, have higher commercial demand and often used in socio-cultural rituals.

Termites occur in the whole Burkina Faso, although, according to farmers, in some areas their availability is limited. In addition, during the rainy season, some species are more difficult to capture than others. Many reasons were given for not using termites. Among them, the lack of knowledge on capturing techniques, unavailability of termites and the lack of time were the most cited. Considering that the lack of knowledge in the collection and trapping techniques has been cited among the main reasons, there is no doubt that these techniques could be optimised and disseminated, which would improve traditional poultry nutrition. However, the fact that no mass production system is available for termites (Kenis et al., 2014) will limit their use among industrial poultry producers. For these, other insects that can be produced at an industrial scale, would be more suitable. Fly larvae such as the black soldier fly (Hermetia illucens L., 1758) or the housefly (Musca domestica L., 1758) are particularly appropriate but others such as mealworm (Tenebrio molitor L., 1758), and even cockroaches, grasshoppers and crickets could be considered since most insects at all life stages are rich sources of animal protein (Józefiak and Engberg, 2015). They have a great potential as feed, taking into account their nutritional value, low space requirement and the fact that they are relished by poultry and fish, since insects belong to their diet in their natural habitat (Rumpold and Schlüter, 2013). 
Table 5. Reasons for not using termites per region. ${ }^{1}$

\begin{tabular}{|c|c|c|c|c|c|c|c|c|}
\hline & Cascades & Centre Ouest & Hauts bassins & Nord & Plateau Central & Centre Sud & Est & Sahel \\
\hline Choice & - & + & - & + & - & - & - & - \\
\hline Lack of interest & + & - & - & - & - & - & - & - \\
\hline Difficult & + & - & - & - & - & + & + & + \\
\hline Distance & - & + & - & - & + & - & - & - \\
\hline Unavailability & - & - & - & - & + & + & +++ & +++ \\
\hline Lack of knowledge on termites & + & + & + & + & + & - & + & + \\
\hline Poultry mortality & + & + & + & - & + & + & + & - \\
\hline No need & + & - & - & - & - & - & + & + \\
\hline Not interested & - & - & - & + & - & + & + & + \\
\hline Lack of time & + & + & + & + & ++ & + & - & + \\
\hline Seasonality of termites & - & - & - & - & + & - & - & - \\
\hline Scarcity of termites & - & - & - & + & - & - & - & - \\
\hline $\begin{array}{l}\text { Lack of knowledge on capturing } \\
\text { techniques }\end{array}$ & - & + & - & + & - & + & + & ++ \\
\hline Toxicity of termites & - & + & - & + & + & - & - & - \\
\hline Too old & + & - & - & - & + & + & - & - \\
\hline Carefulness & - & - & - & - & + & - & - & - \\
\hline
\end{tabular}

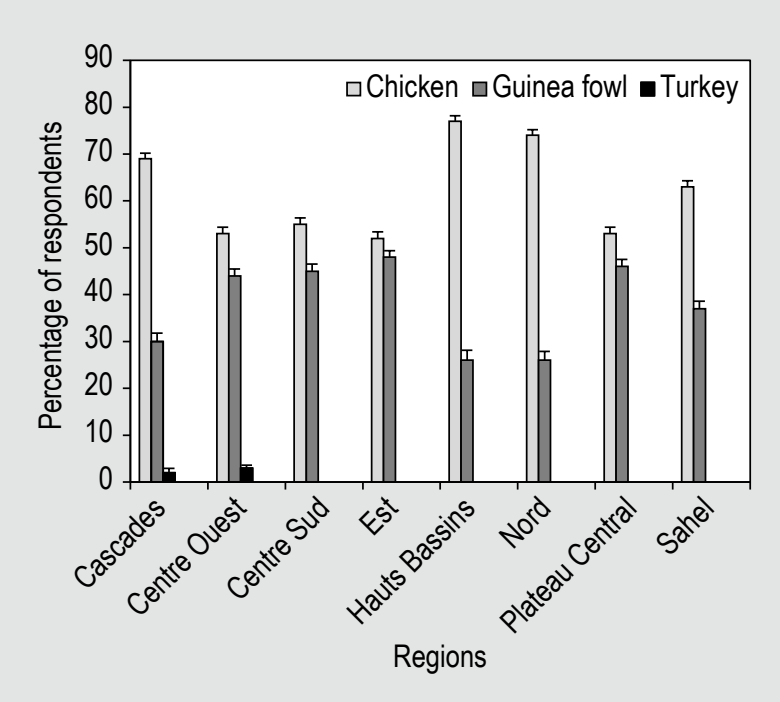

Figure 2. Percentages of farmers claiming that they feed chicken, guinea fowl or turkey with termites in the eight regions. Too few farmers cited duck and pigeons to be shown in the graph. Lines above the bars illustrate standard error.

\section{Conclusions}

Poultry farming is practiced by the vast majority of farmers in Burkina Faso. Termites play an important role in traditional poultry farming since it is often the only source of protein given to domestic fowls and guinea fowls. Farmers of all age categories and sexes collect

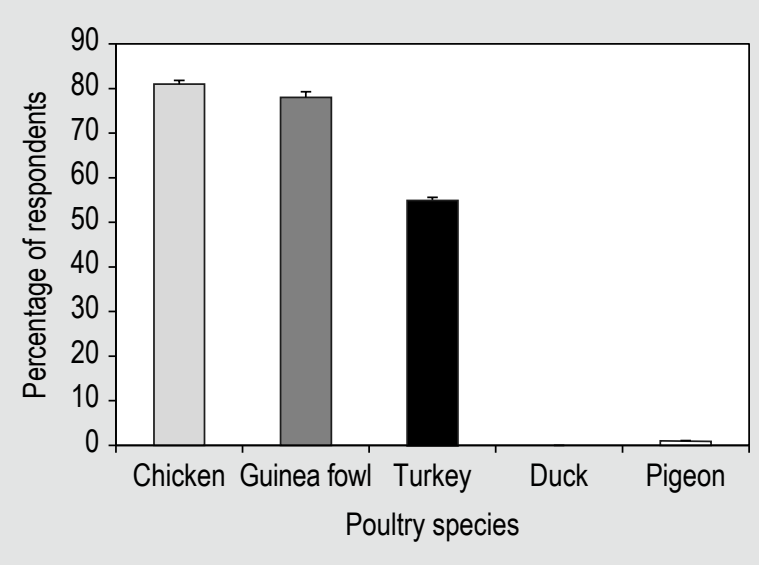

Figure 3. Percentage of the owners of five poultry species that supplement their feed with termites. Lines above the bars illustrate standard error.

termites to supplement poultry feed. However, depending on the region, some constraints may limit their use, in particular seasonal availability, lack of knowledge and lack of time. These result in important variations observed among regions and provinces in the frequency of termite use by farmers. Nevertheless, the fact that termites are already used by a majority of farmers in the country opens perspectives for the improvement of collection and production techniques, which would surely have a positive influence on poultry health and production and, indirectly, on smallholder farmers' livelihood. Experiments are on- 
going in Burkina Faso to compare the different collection methods and improve the trapping system, for example by finding the best attractants or the best trapping designs, and disseminate the most efficient and sustainable methods. In addition to termites, other insects could be used to feed local poultry in smallholder farms. An appropriate species selection based on easiness and suitability for production and characteristics such as safety, protein/ biomass supply on intended use is necessary (Kenis et al., 2014; 2018; Rumpold and Schlüter, 2013). Low-cost production systems that are easily manageable by farmers need to be developed. Fly larvae are particularly adapted to such systems because they can be easily produced on organic wastes at low scales and, in addition, provide by products such as biofertilisers (Koné et al., 2017; Nyakeri et al., 2017; Pomalégni et al., 2017).

\section{Acknowledgements}

We thank the poultry farmers for their time and availability as well as the field agents of the Ministry of Animals Resources for their support during the survey. This study was carried out as part of the project, IFWA - Sustainable use of insects to improve livestock production and food security in smallholder farms in West Africa, funded by the Swiss Agency for Development and Cooperation and the Swiss National Science Foundation, in the framework of the Swiss Programme for Research on Global Issues for Development (R4D). Marc Kenis was partly funded though the CABI Development Fund (supported by contributions from the Australian Centre for International Agricultural Research, the UK's Department for International Development, and others).

\section{References}

Anankware, P.J., Fening, K., Osekre, E. and Obeng-Ofori, D., 2015. Insect as food and feed: a review. International Journal of Agricultural Research and Review 3: 143-151.

Boko, K.C., Kpodekon, T.M., Dahouda, M., Marlier, D. and Mainil, J.G., 2012. Contraintes techniques et sanitaires de la production traditionnelle de pintade en Afrique subsaharienne. Annales de Médecine Vétérinaire 156: 25-36.

Chrysostome, C.A.A.M., Coubéou, P.T., Dakpogan, H. and Mensah, G.A., 2009. Comment collecter des termites avec des noix de rônier pour l'alimentation des pintadeaux? Référentiel technico économique pour la production avicole. Vol. 1. PADAV/CASPA/ OADSA, Cotonou, Bénin.

Chung, A.Y.C., 2010. Edible insects and entomophagy in Borneo. In: Durst, P.B., Johnson, D.V., Leslie, R.N. and Shono, K. (eds.) Forest insects as food: humans bite back. Proceedings of a workshop on Asia-Pacific resources and their potential for development. February 19-21, 2008. Food and Agriculture Organisation Asia-Pacific, Chiang Mai, Thailand, pp. 141-150.
Dembele, Y., 2010. Cartographie des zones socio-rurales du Burkina Faso. Un Outil d'aide à la Planification pour la Gestion de l'Eau en Agriculture. Food and Agriculture Organisation, Rome, Italy.

Diawara, M., 2013. Impact the l'utilisation des termites en aviculture traditionnelle au Burkina Faso. Mémoire de Fin de Cycle. Université Polytechnique de Bobo-Dioulasso, Burkina Faso, 43 pp.

Farina, L., Demey, F. and Hardouin, J., 1991. Production de termites pour l'aviculture villageoise au Togo. Tropicultura 9: 181-187.

Hien, O.C., Diarra, B., Drabo, Y., Boly, H. and Sawadogo, L., 2005. Pratiques de l'aviculture traditionnelle par les différents groupes ethniques de la région des Cascades au Burkina Faso. Agronomie Africaine 17: 227-239.

Institut National de la Statistique et de la Démographie (INSD), 2008. Recensement Général de la Population et de l'Habitation de 2006: Résultats définitifs. INSD, Ministère de l'Economie et des Finances, Burkina Faso, 52 pp.

Institut National de la Statistique et de la Démographie (INSD), 2014. Annuaire statistique 2013. INSD, Burkina Faso, 386 pp.

Józefiak, D. and Engberg, R.M., 2015. Insects as poultry feed. Conference paper of the $20^{\text {th }}$ European Symposium on Poultry Nutrition. August 24-27, 2015. Prague, Czech Republic, 7 pp.

Kagone, H., 1999. Aménagements et équipements pastoraux, Ministère de l'agriculture, Ouagadougou, Burkina Faso, 55 pp.

Kenis, M., Bouwassi, B., Boafo, H., Devic, E., Han, R., Koko, G., Koné, N'G., Maciel-Vergara, G., Nacambo, S., Pomalegni, S.C.B., Roffeis, M., Wakefield, M., Zhu, F. and Fitches, E., 2018. Small-scale fly larvae production for animal feed. In: Halloran, A., Flore, R., Vantomme, P. and Roos, N. (eds.) Edible insects in sustainable food systems. Springer, New York, NY, USA, pp. 239-261.

Kenis, M., Koné, N., Chrysostome, C.A.A.M., Devic, E., Koko, G.K.D., Clottey, V.A., Nacambo, S. and Mensah, G.A., 2014. Insects used for animal feed in West Africa. Entomologia 2: 107-114.

Kondombo, S.R., Nianogo, A.J., Kwakkel, R., Udo, H.M.Y. and Slingerland, M., 2003. Comparative analysis of village chicken production in two farming systems in Burkina Faso. Tropical Animal Health and Production 35: 563574.

Koné, N'G., Sylla, M., Nacambo, S. and Kenis, M., 2017. Production of house fly larvae for animal feed through natural oviposition. Journal of Insects as Food and Feed 3: 177-186.

Lavalette, M., 2013. Les insectes: une nouvelle ressource en protéines pour l'alimentation humaine. Université de Lorraine, Nancy, France, $72 \mathrm{pp}$.

Nougtara, S., 2011. Valorisation des aliments disponibles dans l'alimentation des poulets traditionnels au Burkina Faso. Mémoire du Diplôme d'Ingénieur du Développement Rural: IDR/UPB, BoboDioulasso, Burkina Faso, 89 pp.

Ntukuyoh, A.I., Udiong, D.S., Ikpe, E. and Akpakpan, A.E., 2012. Evaluation of nutritional value of termites (Macrotermes bellicosus): soldiers, workers and queen in the Niger Delta Region of Nigeria. International Journal of Food Nutrition and Safety 1: 60-65.

Nyakeri, E.M., Ogola, H.J., Ayieko, M.A. and Amimo, F.A., 2017. An open system for farming black soldier fly larvae as source of proteins for smallscale poultry and fish production. Journal of Insects for Food and Feed 3: 51-56. 
Ouedraogo, C.L., 2002. Le developpement de l'aviculture familiale: cas du Burkina Faso. Report of the $2^{\text {nd }}$ FAO/INFPD electronic conference on family poultry. Food and Agriculture Organisation / International Network for Family Poultry Development, Rome, Italy.

Ouedraogo, M., 2005. Les termites ailés une ressource précieuse en période de soudure alimentaire au Burkina Faso. Faculté Universitaire des Sciences Agronomiques de Gembloux, Gembloux, Belgium, $26 \mathrm{pp}$.

Pomalégni, S.C.B., Gbemavo, D.S.J.C., Kpadé, C.P., Kenis, M. and Mensah, G.A., 2017. Traditional use of fly larvae by small poultry farmers in Benin. Journal of Insects as Food and Feed 3: 187-192.

Pousga, S. and Boly, H., 2009. Synthèse des travaux de recherche en aviculture au Burkina Faso. Aviculture Familiale 18(1-2): 28-35.

Pousga, S., Boly, H., Lindberg, J.E. and Ogle, B., 2007a. Evaluation of traditional sorghum (Sorghum bicolor) beer residue, shea-nut (Vitellaria paradoxa) cake and cotton seed (Gossypium spp.) cake for poultry in Burkina Faso: availability and amino acid digestibility. International Journal of Poultry Science 6: 666-672.

Pousga, S., Boly, H., Lindberg, J.E. and Ogle, B., 2007b. Effect of supplements based on fishmeal or cottonseed cake and management system on the performance and economic efficiency of exotic hens in Burkina Faso. African Journal of Agricultural Research 2: 496-504.
Rumpold, B.A. and Schlüter, O.K., 2013. Potential and challenges of insects as an innovative source for food and feed production. Innovative Food Science and Emerging Technologies 17: 1-11.

Savadogo, A., 1995. Contribution à l'amélioration de l'élevage de la pintade (Numida meleagris) au Burkina Faso. Mémoire du Diplôme d'Ingénieur du Développement Rural: IDR/UPB, Bobo-Dioulasso, Burkina Faso, 102 pp.

Traore, E.H., 2006. Première évaluation de la structure et de l'importance du secteur avicole commercial et familial en Afrique de l'Ouest: rapport du Sénégal. Food and Agriculture Organisation, Rome, Italy, $52 \mathrm{pp}$.

Van Huis, A., 2003. Insects as food in sub-Saharan Africa. Insect Science and its Application 23: 163-185.

Van Huis, A., Van Itterbeeck, J., Klunder, H., Mertens, E., Halloran, A., Muir, G. and Vantomme, P., 2013. Edible insects: future prospects for food and feed security. FAO Forestry Paper no. 171. Food and Agriculture Organization of the United Nations (FAO), Rome, Italy, 187 pp. Available at: http://www.fao.org/docrep/018/i3253e/ i3253e.pdf. 